\title{
Factors Influencing Biological Control of Sphenoclea zeylanica with Alternaria alternata f. sp. sphenocleae
}

\author{
Rhomela F. Masangkay, Former Graduate Research Student, Timothy C. Paulitz, Associate Professor, and Steven \\ G. Hallett, Former Assistant Professor, Department of Plant Science, Macdonald Campus of McGill University, \\ Ste-Anne-de-Bellevue, Québec, Canada H9X 3V9; and Alan K. Watson, Professor, Department of Plant Science, \\ Macdonald Campus of McGill University, Ste-Anne-de-Bellevue, Québec, Canada H9X 3V9, and Weed Scientist \\ (Seconded from McGill University), International Rice Research Institute, MCPO 3127, 1271 Makati City, Philippines
}

\begin{abstract}
Masangkay, R. F., Paulitz, T. C., Hallett, S. G., and Watson, A. K. 1999. Factors influencing biological control of Sphenoclea zeylanica with Alternaria alternata f. sp. sphenocleae. Plant Dis. 83:1019-1024.

Alternaria alternata f. sp. sphenocleae is an endemic disease causing a few small necrotic foliar lesions and occasionally a foliar blight on Sphenoclea zeylanica, a problem weed in paddy rice. The effects of inoculum concentration, dew period, and plant age on the biocontrol of S. zeylanica with A. alternata f. sp. sphenocleae were studied under controlled environmental conditions. S. zeylanica plants are susceptible from seedling to maturity. When higher inoculum concentrations $\left(10^{6}\right.$ conidia $\mathrm{ml}^{-1}, 10^{8}$ conidia $\left.\mathrm{m}^{-2}\right)$ were applied to plants of different ages with a long dew period, $100 \%$ leaf area damage occurred earlier than when lower inoculum concentrations $\left(10^{4}\right.$ conidia $\mathrm{ml}^{-1}, 10^{6}$ conidia $\left.\mathrm{m}^{-2}\right)$ were used. At the higher inoculum concentrations, a significantly $(\alpha<0.01)$ higher percent reduction in plant height was obtained, and all plants were killed. A dew period of $8 \mathrm{~h}$ was sufficient to cause $100 \%$ mortality when plants were inoculated with $10^{6}$ conidia ml-1, whereas a dew period of $16 \mathrm{~h}$ was required with $10^{4}$ conidia ml ${ }^{-1}$ to achieve the same effect. At all dew periods, a significantly $(\alpha<0.01)$ higher percent dry weight reduction was obtained with higher inoculum concentrations. Field performance of this bioherbicide candidate relies on the primary infection established by inoculum application, as secondary infections have not been observed. Effective use rates can be reduced during the rainy season, while higher rates are required during the dry season.
\end{abstract}

Additional keywords: gooseweed, mycoherbicide

Sphenoclea zeylanica (gooseweed) is a common, annual herbaceous, broadleaf weed species of wetland rice (Oryza sativa) in Southeast Asia, the United States, the Caribbean area, India, Pakistan, and West Africa (11). It is also associated with cotton in Louisiana (20), wheat in ricewheat rotations in India (14), and soybean in rice-soybean rotations in Thailand (26). $S$. zeylanica can reduce yields by as much as $45 \%$ (1), and large yield reductions in transplanted rice can occur at weed densities as low as 20 plants $\mathrm{m}^{-2}(12)$.

Several management strategies are available to control $S$. zeylanica, such as hand weeding, cultural techniques, mechanical methods, and chemical herbicides. The possibility of using an indigenous

Corresponding author: Alan K. Watson

E-mail: a.watson@cgiar.org

Current address of S. G. Hallett: Tropical and SubTropical Weed Research Unit, School of Land and Food, University of Queensland, Gatton College, Queensland 4345, Australia.

Accepted for publication 29 July 1999.

Publication no. D-1999-0914-02R

(c) 1999 The American Phytopathological Society fungal pathogen as a biological control agent is also being investigated (29). In 1991, Alternaria alternata f. sp. sphenocleae was isolated from blighted S. zeylanica collected in a rice field near Los Baños, Laguna, Philippines. A. alternata $\mathrm{f}$. sp. sphenocleae is an endemic disease causing a few small necrotic foliar lesions and occasionally a foliar blight. Laboratory and field studies demonstrated that this fungal pathogen is a promising bioherbicide candidate $(4,15,17,30)$. When a plant is inoculated with spore suspensions, symptom expression is rapid. Conidia germinate on the leaf surface within $6 \mathrm{~h}$ and penetrate 12 to $16 \mathrm{~h}$ after inoculation (4). Leaf curling and flecking are evident within 12 to $24 \mathrm{~h}$. The blight rapidly progresses basipetally from the shoot apex down the stem, and within 1 to 2 weeks, the entire stem is blackened and the plants are killed.

Under natural conditions, infection, disease development, and subsequently, host damage caused by an endemic fungal pathogen are usually suppressed by factors such as low inoculum levels, poor dispersal, adverse environmental conditions, and host tolerance or escape $(10,22,31)$. It is therefore necessary to examine the biology of the pathogen-host interaction and de- termine the optimal environmental conditions for disease development and effective control of $S$. zeylanica by A. alternata $\mathrm{f}$. sp. sphenocleae. The objective of this study was to evaluate the interaction among inoculum concentration of $A$. alternata f. sp. sphenocleae, plant age, and dew period on infection, disease development, and weed control efficacy on S. zeylanica.

\section{MATERIALS AND METHODS}

Inoculum production. Monoconidial isolates of A. alternata f. sp. sphenocleae (IMI 360160) on half-strength potato dextrose agar (1/2 PDA) (Difco, Detroit, MI) were imported from the International Rice Research Institute (IRRI) into the quarantine facility of McGill University in Canada. These monoconidial isolates were then used to inoculate test plant material, reisolated, stored, and maintained on $1 / 2$ PDA in small vials under mineral oil at $4^{\circ} \mathrm{C}$ as stock cultures (24). Small pieces of mycelium from the stock cultures were aseptically transferred to cooled PDA (20 $\mathrm{ml})$ in plastic petri dishes $(90 \mathrm{~mm}$ diameter). Cultures were sealed with Parafilm and incubated at $28^{\circ} \mathrm{C}$ under continuous near-UV (NUV) (J-05, UVP, Inc., Circleville, OH) light for 3 days. Agar plugs (4 $\mathrm{mm}$ diameter) from the margins of young, actively growing colonies were used as seed inoculum (24). Plastic petri dishes (90 mm diameter) with cooled $1 / 2$ PDA (20 ml) were inoculated under aseptic conditions by inverting and placing an agar plug in the center of each dish. Plates were sealed with Parafilm and incubated under either NUV or dark conditions at $28^{\circ} \mathrm{C}$ for 3 to 4 weeks. Conidia were harvested by flooding the plates with $10 \mathrm{ml}$ of sterile deionized water containing $0.01 \%$ Triton X-100 (polyethylene glycol tert-octylphenyl ether) as a wetting agent and gently scraping the surface of the colonies with a sterile glass slide. Resulting suspensions were poured through a $250-\mathrm{mm}$ plastic sieve lined with two layers of sterile cheesecloth. Inoculum concentration was determined with the aid of a hemacytometer and adjusted to the desired concentration with sterile deionized water containing $0.01 \%$ Triton X-100.

Plant production. $S$. zeylanica seeds were soaked with $95 \%$ hydrochloric acid $(\mathrm{HCl})$ for $10 \mathrm{~min}$, washed under continu- 
ous running distilled water for $30 \mathrm{~min}$, and soaked in distilled water at room temperature $\left(24 \pm 2^{\circ} \mathrm{C}\right)$ for $12 \mathrm{~h}$. Seeds were sown in black plastic potting flats $(25 \times 50 \times 6$ $\mathrm{cm})$ two-thirds filled with sterilized soil
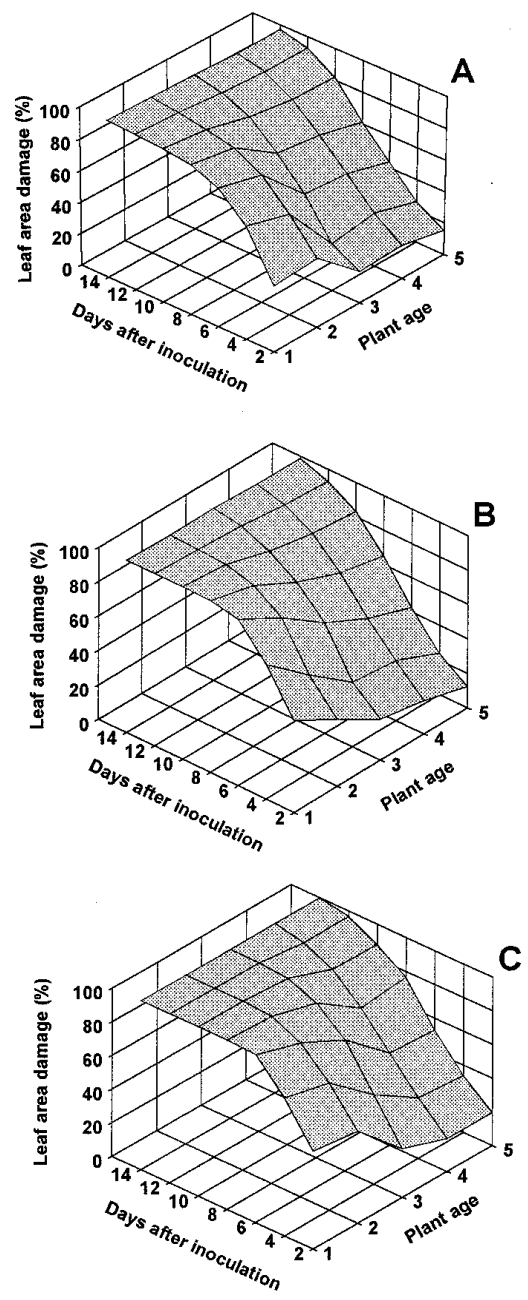

Fig. 1. Effect of inoculum concentration $(\mathbf{A}=$ $10^{4} \mathrm{ml}^{-1}, \mathbf{B}=10^{5} \mathrm{ml}^{-1}, \mathbf{C}=10^{6} \mathrm{ml}^{-1}$ ) and plant age on disease development caused by Alternaria alternata f. sp. sphenocleae on Sphenoclea zeylanica expressed as percent leaf area damage (\% LAD). Plant age was characterized by plant height where age $1=5$ to $6 \mathrm{~cm}$ high, age $2=10$ to $11 \mathrm{~cm}$ high, age $3=15$ to $16 \mathrm{~cm}$ high, age $4=20$ to $21 \mathrm{~cm}$ high, and age $5=25$ to $26 \mathrm{~cm}$ high. Each pot was inoculated with 10 $\mathrm{ml}$ of conidial suspension with $0.01 \%$ Triton X100 as a wetting agent using a hand-held atomizer. Sprayed potted plants were placed in a dark dew chamber with $100 \%$ relative humidity at $24^{\circ} \mathrm{C}$ for $8 \mathrm{~h}$. Relationships were best described by the following equations: (A) $L=$ $52.44+9.56 I-0.4 I^{2}+0.89 I P-19.59 P+$ $0.96 P^{2} ; R^{2}=0.96$, (B) $L=57.76+10.23 I-$ $0.47 I^{2}+1.09 I P-21.45 P+0.85 P^{2} ; R^{2}=0.98$, and (C) $L=60.98+10.51 I-0.55 I^{2}+1.2 I P-$ $18.21 P+0.27 P^{2} ; R^{2}=0.97 . L=$ leaf area damage $(\%), I=$ days after inoculation, $P=$ plant age, and $R^{2}=$ coefficient of determination. Results are from pooled experiments. mixture consisting of 3 parts garden soil, 3 parts Pro-mix (commercial potting mix, Premier Horticulture Inc., Red Hill, PA), 2 parts vermiculite, and 1 part sphagnum peat moss. After sowing, the soil was tamped down and watered until saturation. Seeded trays were placed in a controlled environment chamber (Conviron E15, Winnipeg, MB; $32 / 24^{\circ} \mathrm{C}$ day/night, 400 $\mu \mathrm{E} \cdot \mathrm{m}^{-2} \cdot \mathrm{s}^{-1}$ photosynthetically active radiation (PAR), 12-h day ${ }^{-1}$, and 70 to $80 \%$ relative humidity $[\mathrm{RH}]$ ) until the plants were ready for transplanting. Relative humidity was maintained with a humidifier, soil was kept saturated, and the soil surface was misted every $12 \mathrm{~h}$ using a hand-held atomizer.

Healthy seedlings were selected 21 days after sowing and transplanted (three plants per pot) in transparent plastic containers $(10.5 \mathrm{~cm}$ diameter $\times 7.5 \mathrm{~cm}$ high $)$ halffilled with sterilized moistened soil mixture and fertilized with $10 \mathrm{ml}$ of $20-20-20$ (N-P-K) fertilizer at $1.25 \mathrm{~g} \mathrm{liter}^{-1}$. Plants were maintained in controlled environment chamber conditions as previously described. Pots were flooded with water to a height of 2 to $3 \mathrm{~cm}$ throughout the experimental period.

Plants of different ages, as characterized by plant height, were used in this study. In controlled environmental conditions, the seedlings remained in a very small rosettelike form for 2 weeks, after which the uniculm succulent shoots elongated. Stem branching occurred when plants were 15 to $16 \mathrm{~cm}$ high, flower bud initiation started when plants were 20 to $21 \mathrm{~cm}$ high, and flowering occurred when plants were 25 to $26 \mathrm{~cm}$ high. During the flowering stage, branches also produced flowers.

General inoculation procedure. Each treatment consisted of inoculating three pots of S. zeylanica (three plants per pot) with $10 \mathrm{ml}$ of conidial suspension using a hand-held atomizer. Control treatments were sprayed with deionized water containing the wetting agent. Immediately after spraying, plants were placed in a dark dew chamber (Percival) with $100 \%$ RH at $24 \pm 1^{\circ} \mathrm{C}$ depending on the treatments indicated. Plants were then returned to the controlled environment chamber.

Assessment of disease severity and effect on the host. Disease severity was assessed as percent leaf area damage (\% LAD) and recorded visually every 2 days for 14 days after inoculation (DAI). Plant height, mortality of plants, and dry weight of living aboveground biomass were assessed 14 DAI. Plant height was assessed for each plant by measuring from soil level to the base of the blighted portion of infected stems or to the base of the uppermost leaf of unaffected plants, and results were pooled and averaged for each pot. Plant height data were expressed as percent reduction in plant height compared with plant height of the noninoculated controls. Mortality was evaluated for each plant, and results were pooled and averaged for each pot. Collapsed plants were considered dead, although the succulent stem base of some blighted plants remained green. Dry weight was measured by cutting aerial parts at soil level, and living stem and leaf tissues were dried in paper bags for 7 days at $45^{\circ} \mathrm{C}$ and then weighed. Dead leaves and dead portions of the stem were not included in the dry weight measurements. The dry weight data were expressed as percent reduction in biomass compared with biomass of the noninoculated controls.

Effect of inoculum concentration and plant age. $S$. zeylanica seedlings at different plant heights $(5$ to $6 \mathrm{~cm}, 10$ to $11 \mathrm{~cm}$, 15 to $16 \mathrm{~cm}, 20$ to $21 \mathrm{~cm}$, and 25 to $26 \mathrm{~cm}$ high) were inoculated with concentrations of $0,10^{4}, 10^{5}$, and $10^{6}$ conidia $\mathrm{ml}^{-1}$, equivalent to $0,10^{6}, 10^{7}$, and $10^{8}$ conidia $\mathrm{m}^{-2}$, and then placed in a dark dew chamber with $100 \% \mathrm{RH}$ at $24^{\circ} \mathrm{C}$ for $8 \mathrm{~h}$. Pots were then returned to the controlled environment chamber.

Effect of dew period and inoculum concentration. Plants (16 to $17 \mathrm{~cm}$ high) were inoculated with inoculum concentrations of $0,10^{4}, 10^{5}$, and $10^{6}$ conidia $\mathrm{ml}^{-1}$. After spraying, pots with no supplemental dew were immediately placed in the controlled environment chamber, and the rest of the pots were placed in a dark dew chamber with $100 \% \mathrm{RH}$ at $24^{\circ} \mathrm{C}$ and exposed to dew periods of 8,16 , and $24 \mathrm{~h}$. The controlled environment chamber was darkened to match the dark period in the dew chamber. Following the dew period treatment, pots were returned directly to the controlled environment chamber.

Data analyses. Experiments were arranged in a randomized complete block design with three replicates and were performed twice. Results from the two trials were pooled since homogeneity of variances was confirmed by Bartlett's test (9). All data were examined using analysis of variance (ANOVA). Statistical computations were performed using the Statistical Analysis System (SAS Institute, Cary, NC). All percent data were arcsine transformed prior to analysis of variance (9). Regression analysis was performed on all significant $(\alpha<0.05)$ dependent variables.

\section{RESULTS}

Effect of inoculum concentration and plant age. There was a significant $(\alpha<$ 0.01 ) interaction between inoculum concentration and plant age with percent reduction in plant height, percent mortality, and percent dry weight reduction of $S$. zeylanica inoculated with A. alternata $\mathrm{f}$. sp. sphenocleae. Inoculum concentrations of $10^{5}$ and $10^{6}$ conidia $\mathrm{ml}^{-1}$ applied on 5- to 6-cm-high plants gave $100 \% \mathrm{LAD}$ at 8 DAI (Fig. 1B and C). With an inoculum concentration of $10^{4}$ conidia $\mathrm{ml}^{-1}$, disease expression was delayed and 99\% LAD was attained 14 DAI with the same-sized plants 
(Fig. 1A). This delay in disease expression and slight reduction in disease severity was also observed with 20- to 21-cm-high and 25- to 26-cm-high plants inoculated with $10^{5}$ conidia $\mathrm{ml}^{-1}$ (Fig. 1B). With the highest inoculum concentration $\left(10^{6}\right.$ conidia $\mathrm{ml}^{-1}$ ), $100 \%$ LAD was observed with 20 to 21-cm-high and 25- to 26-cm-high plants at 14 DAI (Fig. 1C).

A linear regression best described the effects of inoculum concentration and plant age on reduction of plant height, plant mortality, and dry weight reduction of $S$. zeylanica inoculated with $A$. alternata $\mathrm{f}$. sp. sphenocleae (Fig. 2). The coefficient of determination $\left(R^{2}\right)$ values were high to moderately high in all instances.

For all plant ages, a conidial suspension of $10^{6}$ conidia $\mathrm{ml}^{-1}$ caused a $100 \%$ reduction in plant height (Fig. 2A). However, reduction in plant height was not significantly $(\alpha<0.01)$ different when 5 - to 6cm-high, 10- to 11-cm-high, and 15- to 16cm-high plants were inoculated with $10^{5}$ conidia $\mathrm{ml}^{-1}$. The lowest percent reduction in plant height $(62 \%)$ was observed with 25- to 26-cm-high plants inoculated with the lowest inoculum concentration $\left(10^{4}\right.$ conidia $\mathrm{ml}^{-1}$ ).

When $10^{6}$ conidia $\mathrm{ml}^{-1}$ were applied to all plant ages, $100 \%$ mortality was obtained (Fig. 2B). Moreover, 100\% mortality was also obtained with 5- to 6-cm-high plants when inoculated with $10^{5}$ conidia $\mathrm{ml}^{-1}$. A lower plant mortality (44 to $61 \%$ ) occurred when $10^{4}$ conidia $\mathrm{ml}^{-1}$ were applied to $15-$ to $16-\mathrm{cm}$-high, $20-$ to $21-\mathrm{cm}-$ high, and 25- to 26-cm-high plants.

Dry weight reduction data (Fig. 2C) reflected mortality in 5- to 6-cm-high plants. With older plants, blight did not extend down the entire stem, and with the lower inoculum density, limited regrowth occurred in some older plants.

Effect of dew period and inoculum concentration. There was a significant ( $\alpha$ $<0.01$ ) interaction between inoculum concentration and dew duration with percent mortality and percent dry weight reduction of $S$. zeylanica inoculated with A. alternata f. sp. sphenocleae. Plants inoculated with $10^{4}$ conidia $\mathrm{ml}^{-1}$ and exposed to $16-$ and 24-h dew periods exhibited $100 \%$ LAD at 14 DAI, and only $6 \%$ LAD occurred at 14 DAI when no dew period followed inoculation (Fig. 3A). Plants inoculated with $10^{5}$ conidia $\mathrm{ml}^{-1}$ and provided with a $24-\mathrm{h}$ dew period exhibited $100 \% \mathrm{LAD}$ at $10 \mathrm{DAI}$, whereas the same effect was obtained after 12 DAI only if the dew period was reduced to $16 \mathrm{~h}$. Even with no supplemental dew, 90\% LAD was nevertheless achieved (Fig. $3 \mathrm{~B})$. With the highest inoculum concentration $\left(10^{6}\right.$ conidia $\left.\mathrm{ml}^{-1}\right), 100 \%$ LAD was obtained at $12 \mathrm{DAI}$ with $8 \mathrm{~h}$ of dew, at 10 DAI with $16 \mathrm{~h}$ of dew, and at 8 DAI with $24 \mathrm{~h}$ of dew; and without supplemental dew, 98\% LAD was observed (Fig. 3C).

A second order regression curve best described the effects of inoculum concentra-
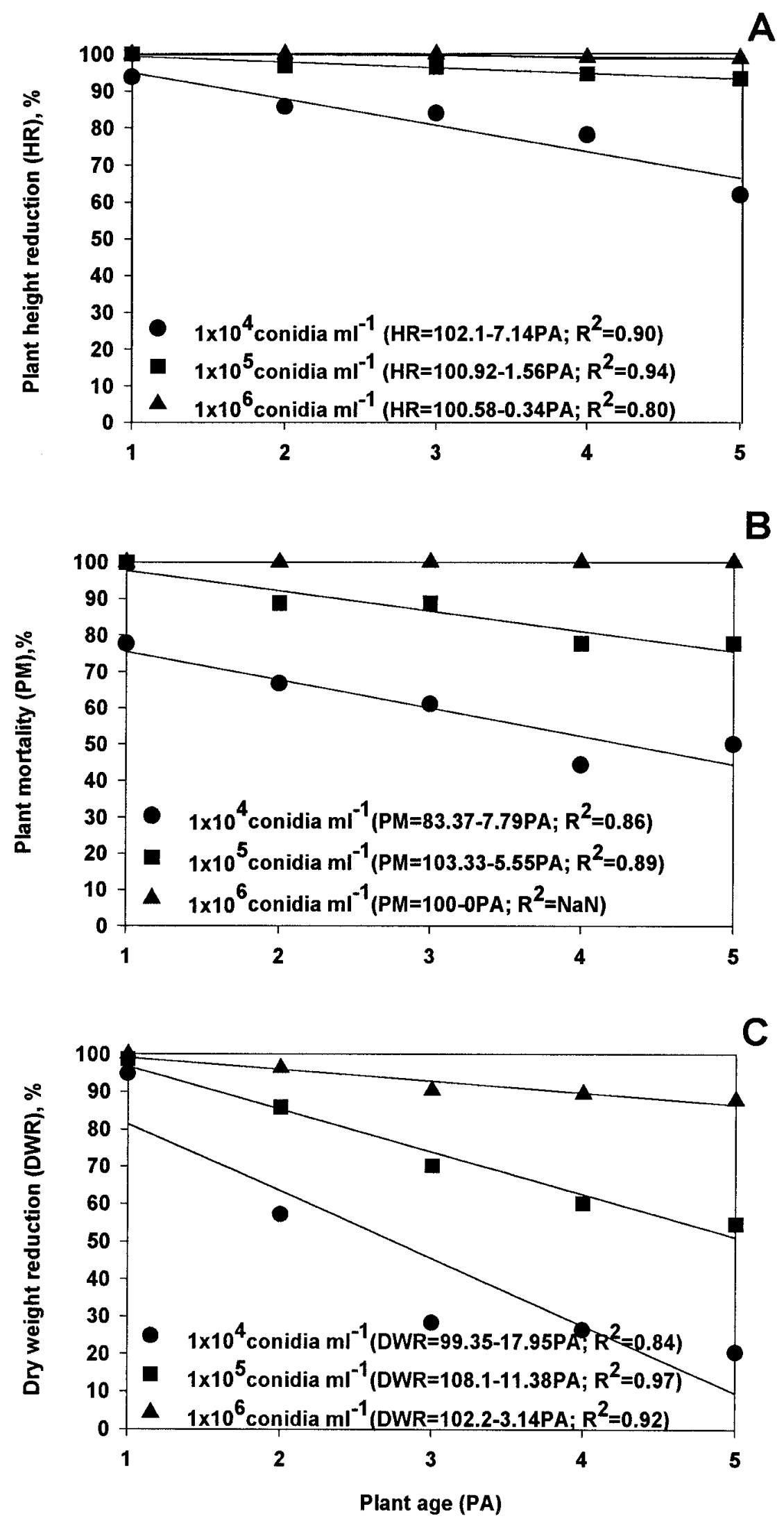

Fig. 2. Effect of inoculum density and plant age on disease development caused by Alternaria alternata f. sp. sphenocleae on Sphenoclea zeylanica expressed as (A) percent reduction in plant height, (B) percent plant mortality, and (C) percent dry weight reduction 14 days after inoculation. Plant age was characterized by plant height where age $1=5$ - to $6-\mathrm{cm}$-high, age $2=10$ to $11 \mathrm{~cm}$ high, age $3=$ 15 to $16 \mathrm{~cm}$ high, age $4=20$ to $21 \mathrm{~cm}$ high, and age $5=25$ to $26 \mathrm{~cm}$ high. Each pot was inoculated with $10 \mathrm{ml}$ of conidial suspension with $0.01 \%$ Triton X-100 as a wetting agent using a hand-held atomizer. Sprayed potted plants were placed in a dark dew chamber with $100 \%$ relative humidity at $24^{\circ} \mathrm{C}$ for $8 \mathrm{~h}$. Results are from pooled experiments. 
tion and dew duration on plant mortality and dry weight reduction of $S$. zeylanica inoculated with $A$. alternata f. sp. sphenocleae (Fig. 4). The $R^{2}$ values were high in all instances.

A dew period of $8 \mathrm{~h}$ was sufficient to cause $100 \%$ mortality when plants were inoculated with $10^{6}$ conidia $\mathrm{ml}^{-1}$. A lower
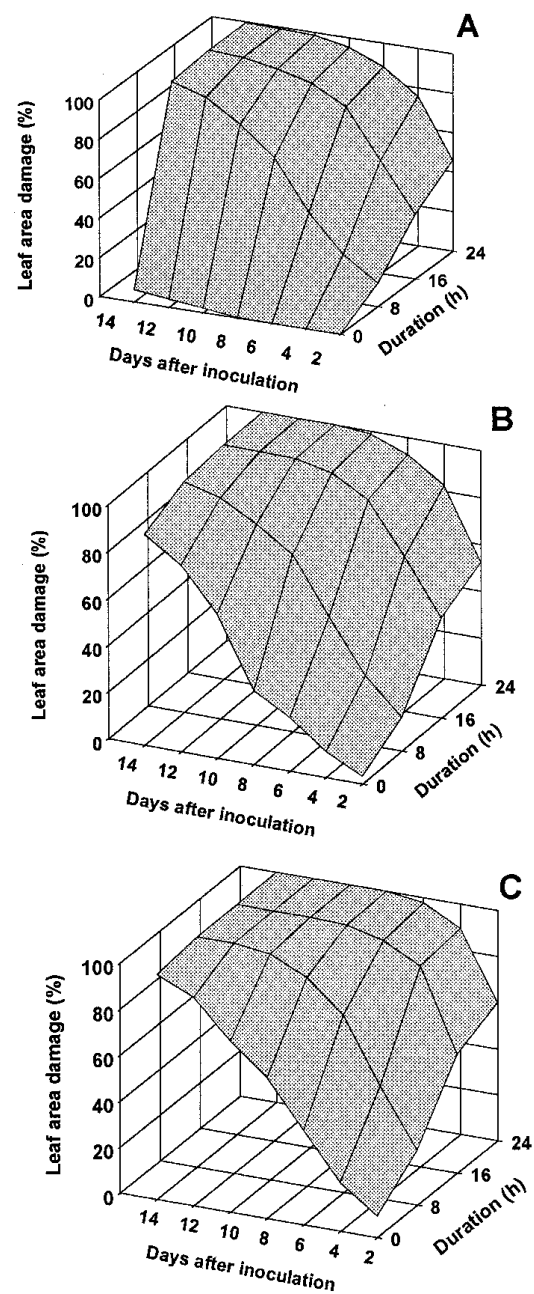

Fig. 3. Effect of inoculum density $\left(\mathbf{A}=10^{4} \mathrm{ml}^{-1}\right.$, $\mathbf{B}=10^{5} \mathrm{ml}^{-1}, \mathbf{C}=10^{6} \mathrm{ml}^{-1}$ ) and dew duration on disease development caused by Alternaria alternata f. sp. sphenocleae on Sphenoclea zeylanica, expressed as percent leaf area damage (\% LAD). Plants (16 to $17 \mathrm{~cm}$ high) were inoculated with $10 \mathrm{ml}$ of conidial suspension with $0.01 \%$ Triton $\mathrm{X}-100$ as a wetting agent using a hand-held atomizer. Sprayed potted plants were placed in a dark dew chamber with $100 \%$ relative humidity at $24^{\circ} \mathrm{C}$. Relationships were best described by the following equations: (A) $L=-41.05+9.34 I-0.38 I^{2}+0.1 I D+$ $7.44 D-0.2 D^{2} ; R^{2}=0.99$, (B) $L=-41.92+$ $14.3 I-0.38 I^{2}-0.21 I D+5.21 D-0.06 D^{2} ; R^{2}=$ 0.96 , and (C) $L=-32.43+16.64 I-0.55 I^{2}-$ $0.24 I D+5.14 D-0.07 D^{2} ; R^{2}=0.97 . L=$ leaf area damage $(\%), I=$ days after inoculation, $D$ $=$ dew period duration, and $R^{2}=$ coefficient of determination. Results are from pooled experiments. inoculum concentration $\left(10^{4}\right.$ conidia $\left.\mathrm{ml}^{-1}\right)$ required a longer dew period $(16 \mathrm{~h})$ to attain the same effect (Fig. 4A). Plants were not killed when they were inoculated with $10^{4}$ conidia $\mathrm{ml}^{-1}$ and had no supplemental dew.

Dry weight reduction of plants inoculated with $10^{6}$ conidia $\mathrm{ml}^{-1}$ and provided with 16 or $24 \mathrm{~h}$ of dew was $100 \%$. This reduction was not significantly $(\alpha<0.01)$ different from that attained with $10^{5}$ conidia $\mathrm{ml}^{-1}$ and submitted to a $24-\mathrm{h}$ dew period (Fig. 4B). The lowest dry weight reduction (18\%) occurred when plants were inoculated with $10^{4}$ conidia $\mathrm{ml}^{-1}$ and had no supplemental dew.

\section{DISCUSSION}

Disease severity and plant mortality caused by A. alternata f. sp. sphenocleae

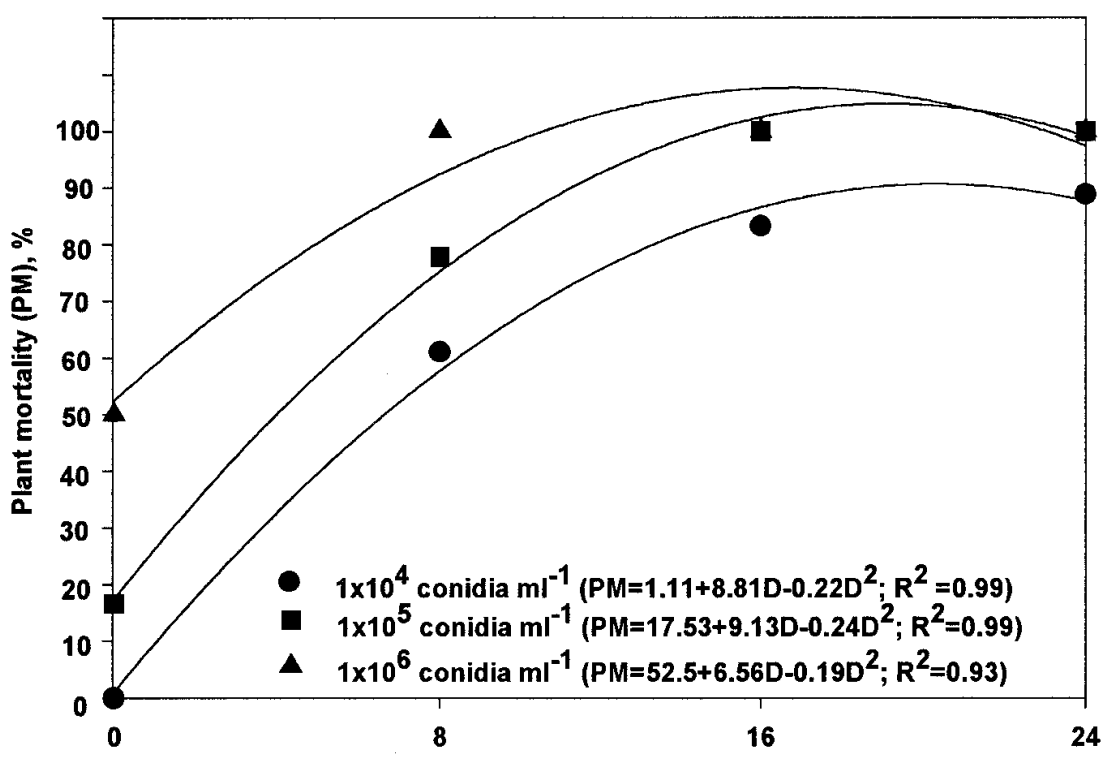

B

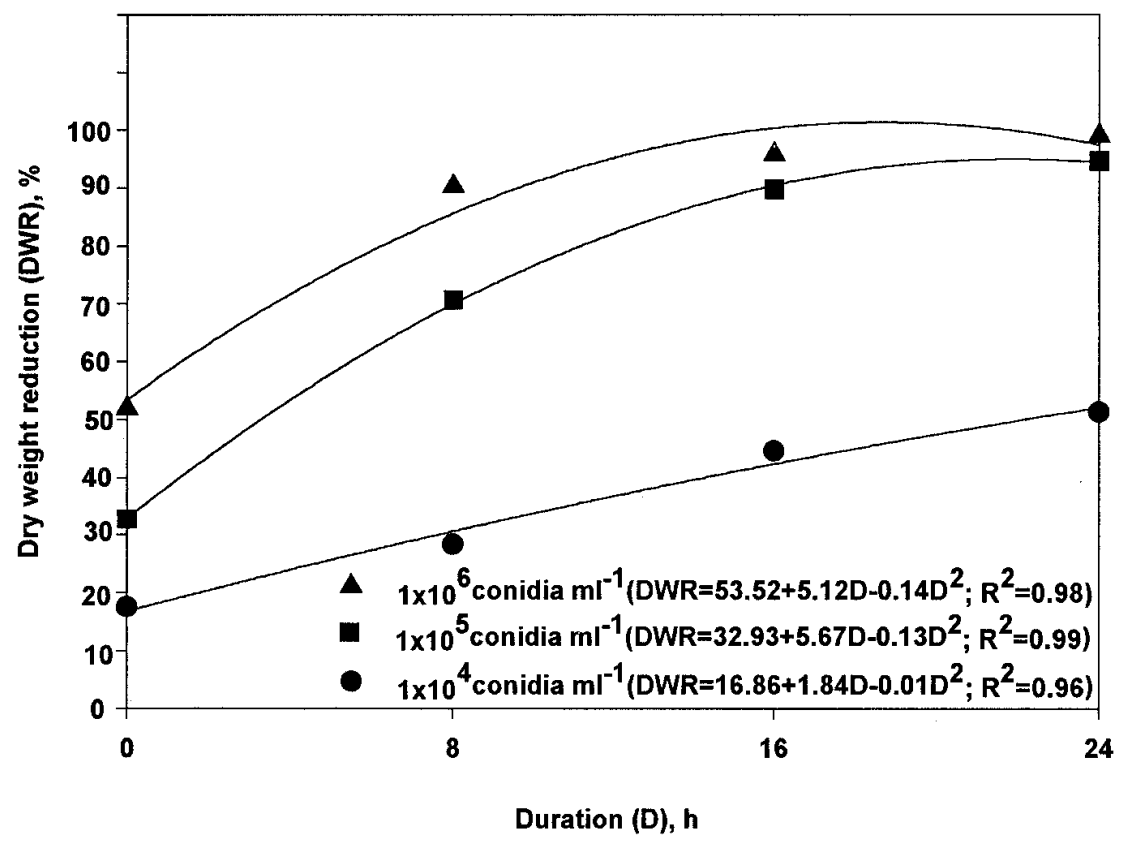

Fig. 4. Effect of inoculum density and dew duration on disease development caused by Alternaria alternata f. sp. sphenocleae on Sphenoclea zeylanica expressed as (A) percent plant mortality and (B) percent dry weight reduction 14 days after inoculation. Plants (16 to $17 \mathrm{~cm}$ high) were inoculated with $10 \mathrm{ml}$ of conidial suspension with $0.01 \%$ Triton X-100 as a wetting agent using a hand-held atomizer. Sprayed potted plants were placed in a dark dew chamber with $100 \%$ relative humidity at $24^{\circ} \mathrm{C}$. Results are from pooled experiments. 
on $S$. zeylanica were influenced by inoculum concentration, dew period, and plant age. Greater disease expression was obtained on plants inoculated with higher inoculum concentrations. The minimum inoculum concentration required for effective control of $S$. zeylanica seedlings was $10^{4}$ conidia $\mathrm{ml}^{-1}$. In a bioherbicide strategy, low application rates capable of causing severe or lethal damage to the host weed are desired to minimize production costs of a bioherbicide product (3).

An important prerequisite for any potential bioherbicide candidate is the determination of the plant stage when the host (weed) is more susceptible to disease (10,31). Unlike most bioherbicide targets, $S$. zeylanica plants are susceptible from seedling to maturity. The susceptibility of S. zeylanica to A. alternata f. sp. sphenocleae did, however, decrease slightly with increasing plant age. Studies of other potential bioherbicides generally report that only younger plants are susceptible to disease $(5,6,23)$, resulting in a narrow application window. By contrast, A. alternata $\mathrm{f}$. sp. sphenocleae application window is the entire growing season.

Key environmental factors affecting disease expression of fungal pathogens are moisture and, to a lesser extent, temperature $(23,31)$. Temperature requirements for A. alternata $\mathrm{f}$. sp. sphenocleae are 20 to $24^{\circ} \mathrm{C}$ for hyphal growth, 24 to $28^{\circ} \mathrm{C}$ for sporulation, and 24 to $30^{\circ} \mathrm{C}$ for germination and disease development (R. F. Masangkay, unpublished). When cultured on solid substrates (sorghum, barley, or wheat seeds), A. alternata f. sp. sphenocleae readily grew and sporulated at 24 and $28^{\circ} \mathrm{C}$, with the most virulent conidia produced at $28^{\circ} \mathrm{C}$ (R. F. Masangkay, T. C. Paulitz, S. G. Hallett, and A. K. Watson, unpublished). Growth and sporulation was inhibited at $32^{\circ} \mathrm{C}$. Temperature conditions in the lowland paddy rice growing area of the Philippines are relatively constant and favorable for disease development of $A$. alternata f. sp. sphenocleae. Minimum temperatures are rarely below $20^{\circ} \mathrm{C}$, and maximum temperatures are commonly around 30 to $35^{\circ} \mathrm{C}$.

Free moisture on the leaf surface is needed for the germination and penetration by infectious propagules of many foliar plant pathogens $(18,34)$. In the field, free moisture may be provided by several natural and human sources: rain, dew, fog, and irrigation (28). The effect of duration of leaf surface moisture is more important than the amount of moisture $(18,25)$. In this study, the minimum dew period to achieve $100 \%$ mortality of S. zeylanica with A. alternata f. sp. sphenocleae was 8 $\mathrm{h}$. This result is similar to those reported for commercial as well as potential bioherbicides, wherein supplementary dew of 8 to $24 \mathrm{~h}$ was required to obtain the highest levels of weed control efficacy $(2,5,16$, $23,27)$. However, this does not conform to the findings of Mabbayad and Watson (15), who reported $100 \%$ mortality of $S$. zeylanica even when no supplemental dew was provided. The differences in these results can be attributed to the environmental conditions to which the inoculated plants were subsequently exposed after dew period treatments. Mabbayad and Watson (15) used a mist room set at $26 \pm$ $2^{\circ} \mathrm{C}$ with 85 to $95 \% \mathrm{RH}$, while in this experiment the controlled environment chamber was set at $32 / 24^{\circ} \mathrm{C}$ day/night with 70 to $80 \%$ RH. Effective control of S. zeylanica in the field has been obtained in both wet and dry seasons $(13,15)$ with relative humidity values of 70 to $90 \%$. These results suggest that high relative humidity is of primary importance for initial infection and concomitant superior weed suppression.

Relative humidity is also critical for the formation of secondary inoculum of Alternaria species. For example, very few conidia of Alternaria porri were formed at 75 to $85 \% \mathrm{RH}$, but conidiation increased with increasing $\mathrm{RH}$ above $85 \%$ (8), and similarly, conidia of $A$. dauci did not form when RH was $96 \%$ or less (21). Sporulation of Alternaria species on infected leaves is influenced by the wetting period, by temperature, and by light (19). Light inhibits sporulation, and even at optimum temperatures, the sporulation process is slow (19). Interrupted wetting periods can result in prolific sporulation of some Alternaria species that require induction during the dryness and light of the day (19). During many field trials in the moist rice paddy fields in the Philippines $(13,15$; $\mathrm{M}$. O. Mabbayad and A. K. Watson, unpublished), the spread of A. alternata f. sp. sphenocleae to adjacent gooseweed plants outside the treated plot area was never observed. Apparently, insufficient secondary inoculum was produced and wind and rain splash dispersal did not occur.

Epidemic records of endemic pathogens are very rare, although one has been recorded for Alternaria macrospora on spurred anoda (Anoda cristata) (32). It was attributed to very high weed host density, a rainy and cool summer with mean temperatures near $25^{\circ} \mathrm{C}$, and the co-occurrence of a rust pathogen, Puccinia heterospora (32). Low initial inoculum levels contribute to the failure of disease epidemics to develop and persist in weed populations (10,31). Disease epidemics rely on a high number of primary infections and subsequent dispersal and secondary infections. Yang and TeBeest (33) argue that bioherbicide research has focused on temperature and moisture requirements of the initial infection and does not address the importance of secondary infection. They proposed a control efficacy model for bioherbicides that includes two components: the primary infection component established by inoculum application and the secondary or postapplication infection component. Unfortunately, this model may not be ap- plicable for most bioherbicides. In most cropping systems, reductions in attainable yield due to weed competition occur within the first 3 to 4 weeks of crop growth. Therefore, the primary infection control component is key to the successful earlyseason suppression of competitive crop weeds. Fungal inoculum is applied inundatively at sufficient dosage to achieve high levels of weed mortality. The Collego (Colletotrichum gloeosporioides f. $\mathrm{sp}$. aeschynomene) northern jointvetch (Aeschynomene virginica) biocontrol system is somewhat atypical. Some yield loss occurs as northern jointvetch begins to shade rice 8 to 10 weeks after emergence, but the greatest loss is in rice quality due to seed contamination with resulting dockage penalties (7). In the Collego situation, secondary infection and spread from initial foci are very important for satisfactory weed control (23).

These laboratory results support the findings of field trials in Talavera, Los Baños, and Baybay in Nueva Ecija, Laguna, and Leyte provinces of the Philippines, where effective control of $S$. zeylanica was obtained in farmers' fields (11,29). Application rates of A. alternata $\mathrm{f}$. sp. sphenocleae can be reduced during periods of rain and high relative humidity, but higher rates will ensure high levels of mortality of $S$. zeylanica during drier periods.

\section{ACKNOWLEDGMENTS}

This work was conducted under a memorandum of agreement between the International Rice Research Institute (IRRI) and McGill University. This work was funded in part by the United Nations Development Program (UNDP) grant GLO/91/001/A/01/42 to IRRI and by the Natural Sciences and Engineering Research Council of Canada (NSERC) Operating Grants to SGH and AKW.

\section{LITERATURE CITED}

1. Ampong-Nyarko, K., and de Datta, S. K. 1991. A Handbook for Weed Control in Rice. International Rice Research Institute, Manila, Philippines.

2. Anderson, R. N., and Walker, H. L. 1985 Colletotrichum coccodes: A pathogen of eastern black nightshade (Solanum ptycanthum). Weed Sci. 33:902-905.

3. Baker, C. A., and Henis, J. M. S. 1990. Commercial production and formulation of microbial biocontrol agents. Pages 333-344 in: New Directions in Biological Control: Alternatives for Suppressing Agricultural Pests and Diseases. R. R. Baker and P. E. Dunn, eds. Alan R. Liss, New York.

4. Bayot, R. G., Watson, A. K., and Moody K. 1994. Control of paddy weeds by plant pathogens in the Philippines. Pages 139-143 in: Integrated Management of Paddy and Aquatic Weeds in Asia. H. Shibayama, K. Kiritani, and J. Bay-Petersen, eds. FFTC Book Series 45. Food and Fertilizer Technology Center for the Asian and Pacific Region, Taipei.

5. Boyette, C. D., and Walker, H. L. 1985. Factors influencing biocontrol of velvetleaf (Abutilon theophrasti) and prickly sida (Sida spinosa) with Fusarium lateritium. Weed Sci. 33: 209-211.

6. Charudattan, R. 1990. Pathogens with poten- 
tial for weed control. Pages 132-154 in: Microbes and Microbial Products as Herbicides. R. E. Hoagland, ed. American Chemical Society Symposium Series 439, Washington, DC.

7. Daniel, J. T., Templeton, G. E., Smith, R. J., Jr., and Fox, W. T. 1973. Biological control of northern jointvetch with an endemic fungal disease. Weed Sci. 21:303-307.

8. Everts, K. L., and Lacy, L. M. 1990. The influence of dew duration, relative humidity, and leaf senescence on conidial formation and infection of onion by Alternaria porri. Phytopathology 80:1203-1207.

9. Gomez, K. A., and Gomez, A. A. 1994. Statistical Procedures for Agricultural Research. 2nd ed. John Wiley \& Sons, New York.

10. Holcomb, G. E. 1982. Constraints on disease development. Pages 61-71 in: Biological Control of Weeds with Plant Pathogens. R. Charudattan and H. L. Walker, eds. John Wiley \& Sons, New York.

11. Holm, L. G., Plucknett, D. L., Pancho, J. V., and Herberger, J. P. 1977. Sphenoclea zeylanica. Pages 446-449 in: The World's Worst Weeds, Chapter 71. University Press, Honolulu, HI.

12. International Rice Research Institute. 1989. Annual Report for 1988. International Rice Research Institute, Manila, Philippines.

13. International Rice Research Institute. 1995. Program Report for 1994. International Rice Research Institute, Manila, Philippines.

14. Khan, N. A., Khan, M. I., Ghafoor, A., and Shad, R. A. 1988. Optimising quadrat size and quadrat number for weed species count studies in transplanted rice. Indian J. Weed Sci. 20:36-39.

15. Mabbayad, M. O., and Watson, A. K. 1995. Biological control of gooseweed (Sphenoclea zeylanica Gaertn.) with an Alternaria sp. Crop Prot. 14:429-433.

16. Makowski, R. M. D. 1993. Effect of inoculum concentration, temperature, dew period, and plant growth stage on disease of round-leaved mallow and velvetleaf by Colletotrichum gloeosporioides f. sp. malvae. Phytopathology 83:1229-1234.

17. Masangkay, R. F., Mabbayad, M. O., Paulitz, T. C., and Watson, A. K. 1999. Host range of Alternaria alternata f. sp. sphenocleae causing leaf blight of Sphenoclea zeylanica. Can. J. Bot. 77:103-112.

18. Rotem, J. 1978. Climatic and weather influences on epidemics. Pages 317-337 in: Plant Disease: An Advanced Treatise, Vol. 2. J. G. Horsfall and E. B. Cowling, eds. Academic Press, New York.

19. Rotem, J. 1994. The Genus Alternaria: Biology, Epidemiology, and Phytopathology. American Phytopathological Society, St. Paul, $\mathrm{MN}$.

20. Sanders, D. E. 1990. Documentation of weed infestation levels in Louisiana cotton. Page 357 in: Proc. Beltwide Cotton Prod. Res. Conf., Memphis, TN.

21. Strandburg, J. O. 1977. Spore production and dispersal of Alternaria dauci. Phytopathology 67:1262-1266.

22. TeBeest, D. O. 1991. Ecology and epidemiology of fungal pathogens studied as biocontrol agents of weeds. Pages 97-114 in: Microbial Control of Weeds. D. O. TeBeest, ed. Chapman \& Hall, New York.

23. TeBeest, D. O., and Templeton, G. E. 1978. Temperature and moisture requirement for development of anthracnose on northern jointvetch. Phytopathology 68:389-393.

24. Tuite, J. 1969. Plant Pathological Methods: Fungi and Bacteria. Burgess Publishing Co., Minneapolis, MN.

25. Van der Wal, A. F. 1978. Moisture as a factor in epidemiology and forecasting. Pages 253295 in: Water Deficits and Plant Growth, Vol. 5. T. T. Kozlowski, ed. Academic Press, New York.

26. Vongsaroj, P. 1994. Integrated management of paddy weeds in Thailand. Pages 32-45 in: Integrated Management of Paddy and Aquatic
Weeds in Asia. H. Shibayama, K. Kiritani, and J. Bay-Petersen, eds. FFTC Book Series 45. Food and Fertilizer Technology Center for the Asian and Pacific Region, Taipei.

27. Walker, H. L., and Boyette, C. D. 1986. Influence of sequential dew periods on biocontrol of sicklepod (Cassia obtusifolia) by Alternaria cassiae. Plant Dis. 70:962-963.

28. Wallin, J. R. 1963. Dew, its significance and measurement in phytopathology. Phytopathology 53:1210-1216.

29. Watson, A. K. 1994. Current status of bioherbicide development and prospects for rice in Asia. Pages 195-201 in: Integrated Management of Paddy and Aquatic Weeds in Asia. $\mathrm{H}$. Shibayama, K. Kiritani, and J. Bay-Petersen, eds. FFTC Book Series 45. Food and Fertilzer Technology Center for the Asian and $\mathrm{Pa}-$ cific Region, Taipei.

30. Watson, A. K., Mabbayad, M. O., Zhang, W., Masangkay-Watson, R. F., De Luna-Couture, L. Z., Yandoc, C. B., Paulitz, T. C., and Mortimer, A. M. 1997. Progress of a biological weed control project in rice-based cropping systems in Southeast Asia. Pages 342-344 in: Proc. Asian Pacific Weed Sci. Soc. Conf, 16th. A. Rajan, ed. Malaysian Plant Protection Society, Kuala Lumpur.

31. Watson, A. K., and Wymore, L. A. 1990. Identifying limiting factors in the biocontrol of weeds. Pages 305-316 in: New Directions in Biological Control: Alternatives for Suppressing Agricultural Pests and Diseases. R. R. Baker and P. E. Dunn, eds. Alan R. Liss, New York.

32. Yang, X. B., and TeBeest, D. O. 1993. An epidemic record of endemic Alternaria blight of spurred anoda. Plant Dis. 77:1164-1167.

33. Yang, X. B., and TeBeest, D. O. 1993. Epidemiological mechanisms of mycoherbicide effectiveness. Phytopathology 83:891-893.

34. Zadoks, J. C., and Schein, R. D. 1979. Epidemiology and Plant Disease Management. Oxford University Press, New York. 